\title{
Study Investigator Identifier
}

National Cancer Institute

\section{Source}

National Cancer Institute. Study Investigator Identifier. NCI Thesaurus. Code C94088.

A unique symbol that establishes identity of the study investig ator. 